\title{
The Effects of Organizational and Political Factors on the Development of Performance Measurement System (PMS) of Local Government Institutions
}

\author{
Parwoto* ${ }^{1}$ and Abdul Halim ${ }^{2}$
}

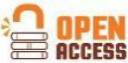

\section{AFFILIATION:}

${ }^{1}$ Department of Accounting, Vocational Program Universitas Muhammadiyah Yogyakarta, Daerah Istimewa Yogyakarta, Indonesia

2 Department of Accounting, Faculty of Economics and Business Universitas Gadjah Mada, Daerah Istimewa Yogyakarta, Indonesia

\section{*CORRESPONDENCE:}

parwoto@umy.ac.id

THIS ARTICLE IS AVALILABLE IN:

http://journal.umy.ac.id/index.php/ai

DOI: 10.18196/jai.2102146

\section{CITATION:}

Parwoto, \& Halim, A. (2020). The Effects of Organizational and Political Factors on the Development of Performance Measurement System (PMS) of Local Government Institutions . Journal of Accounting and Investment, 21(2), 217-239.

\section{ARTICLE HISTORY}

Received:

4 Aug 2019

Reviewed:

5 Sep 2019

3 May 2020

Revised:

16 Des 2019

7 Apr 2020

Accepted:

14 Apr 2020
Abstract:

Research aims: This study aims to examine the influence of organizational and political factors on the development of performance measurement systems (PMS) based on its development purpose and identify the phenomenon of institutional isomorphism.

Design/Methodology/Approach: This research uses mixed methods with sequential explanatory strategies. Quantitative data were obtained by survey using questionnaires and qualitative data collection using semi-structured interviews. Quantitative data analysis uses SEM PLS, and qualitative data analysis uses Content Analysis (CA).

Research findings: This research shows that the open attitude of the local government apparatus in accepting change, strong commitment from the leaders, broad enough authority for management, and strong political support from internal and external determine the success of the PMS development process in local government institutions. Furthermore, the phenomenon of institutional isomorphism is also still found in the PMS development process in local government institutions.

Theoretical Contribution/ Originality: This study complements previous research on the factors that influence the development of PMS and adds evidence that the phenomenon of institutional isomorphism exists in the PMS development process. Research in this field has not been much researched in public sector accounting, particularly in Indonesia.

Practitioner/Policy implication: This research provides input to the local government regarding the factors that need to be considered in the PMS development process, so that the PMS development policy is successful and can improve the performance of the local government.

Research limitation/Implication: The minimum number of respondents who are willing to be interviewed and the research sample is only limited in the province of Daerah Istimewa Yogyakarta (DIY) is a limitation in this study that might affect the results. Further research is recommended to continue using the mixed methods by expanding the distribution area of the sample used and adding other variables that are considered influential and able to capture the phenomenon of institutional isomorphism in the PMS development process.

Keywords: Organizational Factors; Political Factors; PMS Development; Mixed Methods 


\section{Introduction}

The implementation of the performance measurement system (PMS) is believed to be essential in efforts to improve government performance, especially in realizing the goals and objectives, efficiency, effectiveness of public services in a transparent manner, assisting in the allocation of resources and decision making (Sihaloho \& Halim, 2005), realizing public accountability, and improving institutional communication (Mardiasmo, 2009). PMS is the main key in creating effective, efficient, and accountable public sector management (Spékle \& Verbeeten, 2009). However, so far, the implementation of PMS, especially in local governments in Indonesia, is still not in accordance with the objectives of the PMS implementation itself (Sofyani, Akbar, \& Ferrer, 2018). The implementation and policies for developing PMS carried out by many government agencies in Indonesia only aim to fulfill and comply with the provisions of the central government and parliament, not fully to improve performance and real public accountability (Sihaloho \& Halim, 2005; Akbar, Pilcher, \& Perrin 2012; Sofyani et al., 2018). The above facts reinforce the notion that the implementation and development of PMS carried out by many government institutions in Indonesia is limited to meeting regulatory pressure (Sihaloho \& Halim, 2005), and only formalities (Akbar et al. 2012), so that it is still questioned (Nurkhamid, 2008). Therefore, it is not surprising if the resulting performance is still considered pseudo, biased, and tends to be doubted (Ahyarudin \& Akbar, 2017). This condition is in accordance with the institutional theory, which explains that the main reason underlying organizational change is because it aims to gain legitimacy rather than improve the substantive performance of the organization (Ashworth, Boyne, \& DelBridge, 2009). Frumklin and Galaskiewicz (2004) add that performance measures are less precise in budgeting but are still used by local governments in developing performance indicators more because of the influence of institutional pressures.

Several studies in Indonesia concerning factors that influence the implementation and development of PMS, among others, have been conducted by Nurkhamid (2008), Diptyana and Basuki (2010), Yowi (2011), Primarisanti (2013), Sofyani and Akbar (2013). However, these studies still show mixed results. Therefore, a study of the objectives of developing PMS by government agencies and the factors that influence it is essential to do. This study is a development of Syachbrani (2013), who found that employee training factors and organizational culture influenced the development of PMS for exploration purposes. Difficulty factors determining performance measures and educational background have been shown to influence the development of PMS for incentive purposes. Meanwhile, the factors that influenced the development of PMS for operational purposes have not yet been found. Departing from the suggestion of Syachbrani (2013), this study examines organizational and political factors towards the purpose of developing PMS in Local Government Agencies by using mixed methods. It considers that the characteristics of public sector organizations, multidimensional performance measures, and the diversity of stakeholders are thought to be separate obstacles for government agencies in developing PMS (Mardiasmo, 2009). The organizational factors used in this study include organizational responses that are open 
to change, management commitment, and decision-making authority. Whereas, political factors include: internal support and external support.

Variable of organizational responses that are open to change refers to Julnes and Holzer (2001), who found that organizational responses that were open to change had a positive effect on the implementation of a new system. The variables of management commitment and decision-making authority refer to Cavaluzzo and Ittner (2004), who stated that management commitment and decision-making authority influenced the successful implementation of performance measurement systems. Furthermore, internal support and external support variables refer to Julnes and Holzer (2001), who affirmed that political factors in the form of internal support and external support, were thought to influence the adoption and implementation stages of performance measures. Wang (2000) also found that political support was proven to be positively related to the use of performance measures in budgeting. This opinion is reinforced by Pollit (2001) in Cohen (2014), who revealed that government policies without strong support and serious political interests, tend to be difficult to achieve. Consistent executive support, legislative recognition of new information, and organizational capacity are often cited as vital components for determining the effectiveness of performance measurement systems (Berman \& Wang, 2000). The goal variable of PMS development refers to three different roles of public sector organizations, according to Speklé and Verbateen (2009).

The results of this study are expected to be able to contribute to the development of the Institutional Isomorphism Theory, especially related to important factors that need to be considered in developing PMS so that the goals of PMS development can be substantively achieved. Besides, the results of this study are expected to provide benefits and consideration for policymakers and practitioners in local governments in developing PMS so that the quality of PMS implementation increases.

\section{Literature Review and Hypotheses Development}

\section{Institutional Theory}

Organizations are formed by forces from outside the organization through the process of obedience (compliance), imitation, and cognitive processes (DiMaggio \& Powell, 1983). Organizations respond to pressures emanating from their institutional environment, so their choices regarding the adoption of procedures or structures will be driven by what is socially accepted as the right way to act (DiMaggio Powell, 1983). An organization must be able to convince the community as a legitimate entity so that it deserves support from the community (Meyer \& Rowan, 1977). Institutional pressure can act as a strong force that causes an organizational change (Buckho, 1994). Organizations that have legitimacy will have the same isomorphism to adjust and follow where the organization depends (DiMaggio \& Powell, 1983). The pressure that arises in institutions raises three mechanisms of change, which are referred to as institutional 
The Effects of Organizational and Political Factors ...

isomorphism, namely coercive isomorphism, mimetic isomorphism, normative isomorphism (DiMaggio \& Powell, 1983).

Coercive isomorphism is a formal or non-formal pressure from other organizations that urges an organization to adjust and follow where the organization depends (DiMaggio \& Powell, 1983). The main factor of this coercive pressure is political influence and legitimacy. Mimetic isomorphism is an action carried out by an organization by imitating the standards of practices and policies used by other organizations (DiMaggio \& Powell, 1983). Normative isomorphism is the pressure that comes from professionalization. Professionalization builds a cognitive and legitimacy base for organizational autonomy (DiMaggio \& Powell, 1983).

\section{Development of Performance Measurement Systems (PMS)}

The development of PMS is a process of gathering performance measures, which is reported regularly through an organization's information system (Cavalluzo \& Ittner, 2004). An appropriate measure of performance will be able to help the organization know how well a program is being implemented, the achievement of an activity's objective, the level of customer satisfaction, the statistical control of the process of activity, and the development needed for an activity. Thus, the development of a PMS will be reflected in the development of various performance measures that will be used by an organization (Nurkhamid, 2008).

Speklé and Verbeeten (2014) suggest that PMS can serve a different purpose than public sector organizations. The purpose of developing and using PMS can be seen by examining the three different roles of public sector organizations, namely: (1) systems that can be applied for operational purposes, (2) systems that can be used to provide incentives and awards, and (3) systems that can be employed for exploration purposes. First, the stem that can be applied for operational purposes includes planning to the monitoring process. Second, a system that can be used for the provision of incentives and awards contains the application of the system of reward and punishment in accordance with PMS functions as the organization's control. Furthermore, the system can be employed for exploration for double-loop learning, priority setting, and policy development, because exploring strategic capability is a core or backbone of the success of the bureaucracy reform (Wijaya \& Akbar, 2013).

Based on the opinion of Speklé and Verbeeten (2014), this study focuses on analyzing the influence of organizational and political factors on the development of PMS from aspects of operational purposes, incentives or rewards purposes, and exploration purposes, as conducted by Syachbrani (2013), and Wijaya and Akbar (2013). According to Speklé and Verbeeten (2014), the three roles of developing differentiated PMS are not mutually exclusive. It indicates that the use of one of the system roles does not mean rejecting the use of another role (Mardiasmo, 2009). In other words, it can use different roles, and it can also be used together. 


\section{Organizational Factors in PMS Development}

\section{Organizational response open to change}

The demand for massive changes in the culture of the performance of government agencies was marked by the issuance of Presidential Instruction No. 7 of 1999 concerning Government Agency Performance Accountability. The mandate of the Presidential Instruction will only run successfully if the government organization, as the trustee, accepts the cultural change of the organization openly. The implementation of the presidential instruction mandate results in changes in organizational attitudes. Organizational culture in government bureaucracies tends to be resistant to change (resistance to change) and slow to accept innovation (Rainey, 1999). Therefore, these cultural changes are determined mainly by the attitude of the organization in accepting change innovations.

Julnes and Holzer (2001) found that the behavior (attitude) of organizational members in responding to change had a positive effect on the implementation of a PMS. Nurkhamid (2008) and Yowi (2011) succeeded in proving that organizational culture had a positive impact on the development of PMS. Meanwhile, Sofyani and Akbar (2013) managed to find that the response of organizations that were open to change had a positive influence on the development of PMS. This study used organizational response variables that were open to addressing changes in organizational culture (Julnes \& Holzer, 2001), and the subsequent effects were tested on the objectives of PMS development.

$\boldsymbol{H}_{1 a}$ : Organizational responses that are open to change have a positive effect on the development of PMS for operational purposes.

$\boldsymbol{H}_{1 b}$ : Organizational responses that are open to change have a positive effect on the development of PMS for incentive purposes.

$\boldsymbol{H}_{1 c}$ : Organizational responses that are open to change have a positive effect on the development of PMS for exploration purposes.

\section{Management commitment}

Robbins and Judge (2011) define commitment as a condition in which an individual takes sides the organization and its goals and desires to maintain its organizational membership. Management commitment is important in the process of designing, implementing, and using a PMS (Sofyani \& Akbar, 2013). In the perspective of institutional isomorphism, management commitment is normatively a form of the collective struggle of organizational members to determine the conditions and methods of their work for goals that lead to professionalism (DiMaggio \& Powell, 1983). Cavalluzzo and Ittner (2004) state that management commitment can be realized in the form of strong leadership commitment in achieving goals, and strategies on various 
plans that are considered valuable. The management leader who has a strong commitment to the organization he leads is expected to be able to direct organizational resources to develop PMS professionally.

Research of Nurkhamid (2008) successfully proved that management commitment had a positive effect on the development of PMS. However, Yowi (2011), Primarisanti (2013), and Sofyani and Akbar (2013) failed to find the effect of management commitment on the development of PMS in local government agencies. This study would examine the effect of management commitment on the objectives of developing PMS.

$\boldsymbol{H}_{2 a}$ : Management commitment has a positive effect on the development of PMS for operational purposes.

$\boldsymbol{H}_{2 b}$ : Management commitment has a positive effect on the development of PMS for incentive purposes.

$\boldsymbol{H}_{2 c}$ : Management commitment has a positive effect on the development of PMS for exploration purposes.

Decision-making authority

Decision-making authority is a condition where a person has the authorization or right to make decisions with pre-determined requirements to achieve the organization's strategic goals (Cavalluzo \& Ittner, 2004). The implementation of PMS often fails because employee involvement factors are not considered (The Urban Institute, 2002). The organization personnel needs to be given the authority to make their performance measures or targets and to achieve these targets in accordance with the rules (rules of the game) that apply in the organization (Sihaloho \& Halim, 2005). The decision making given to management had a positive effect on the development of PMS, performance accountability, and the use of performance information resulting from the implementation of the PMS (Cavalluzzo \& Ittner, 2004). The decision-making authority given to the leadership of the organization gives authority to determine the conditions, methods of working for the organization, develop cognitively, and legitimize the autonomy of their work, which leads to professionalism (DiMaggio and Powell, 1983).

Sofyani and Akbar (2013) have not succeeded in finding the influence of decision-making authority on the development of PMS. However, Nurkhamid (2008) and Primarisanti (2013) succeeded in proving that decision-making authority influenced the development of PMS. Based on the findings of the previous research above, this study would investigate the influence of decision-making authority on the objectives of developing PMS.

$\boldsymbol{H}_{3 a}$ : Decision-making authority has a positive effect on the development of PMS for operational purposes. 
$\boldsymbol{H}_{3 b}$ : Decision-making authority has a positive effect on the development of PMS for incentive purposes.

$\boldsymbol{H}_{3 c}$ : Decision-making authority has a positive effect on the development of PMS for exploration purposes.

\section{Political Factors in Development of PMS}

Internal support

The decision making in public sector organizations is inseparable from the political influence of organizations originating from outside and from within the organization. Politics in organizations is an action taken by stakeholder groups to influence decisions (Morrow \& Hitt, 2000). Whereas, internal support is the level of support of leaders and employees for performance measures, and as an internal political proxy (Sihaloho \& Halim, 2005). Politics in organizations can arise when there is no agreement from the elements in the organization that have the potential to cause conflict (Morrow \& Hitt, 2000).

The adoption of a performance measure is an internal process within the organization. Internal support and agreement largely determine the success of the adoption process, implementation, and utilization of performance information so that the role of leaders and management levels is needed to be able to reach internal organizational agreements in adopting a measure of performance (Diptyana \& Basuki, 2010). Internal support in the form of involvement and agreement of program personnel in developing performance measures, as well as leadership initiatives in dealing with conflict, are very influential in adopting performance measures (Julnes \& Holzer, 2001).

Julnes and Holzer (2001), as well as Sihaloho and Halim (2005), found that internal support had a positive effect on the process of adopting performance measures. Furthermore, Diptyana and Basuki (2010) also found that the participation of internal stakeholders had a positive effect on the process of developing performance measures. This study would analyze the impact of internal support on the objectives of developing PMS, which included operational purposes, incentive purposes, and exploration purposes.

$\boldsymbol{H}_{4 a}$ : Internal support has a positive effect on the development of PMS for operational purposes.

$\boldsymbol{H}_{4 b}$ : Internal support has a positive effect on the development of PMS for incentive purposes.

$\boldsymbol{H}_{4 c}$ : Internal support has a positive effect on the development of PMS for exploration purposes. 


\section{External support}

External support is the level of legislative and public (public) support for performance measures (Diptyana \& Basuki, 2010). This support can be in the form of allowing allocation of resources planned by the organization, supporting the use of specific performance measures, and using the information on PMS results, even though the information is contrary to its political agenda (Sihaloho \& Halim, 2005). External support is seen as an important thing in the use of performance measures and the form of efficiency expectations and demands for accountability from the community (Julnez \& Holzer, 2001).

The success of PMS implementation is influenced by the support of legislators and the public. Political support is essential, especially for local governments that have political instability (Gron \& Salomonsen, 2017). In addition, public support is also needed in the adoption and implementation of new policies (Wicki, Huber, \& Berauer 2019; Masuku \& Jili, 2019). Toshkov, Mader, and Rasmussen (2018) proved that legislative support and public support had a positive effect on policy change. However, politicized policy practices can undermine the legitimacy of results and weaken democracy (Hinterleitner, 2018).

Wang (2000), Julnes and Holzer (2001), Diptyana and Basuki (2010) showed that external support significantly influenced the development of performance measures. Julnes and Holzer (2001) and Sihaloho \& Halim (2005) found that external support did not significantly influence the implementation of performance measurement. This study would scrutinize the influence of external support toward the objectives of developing PMS.

$\boldsymbol{H}_{5 a}$ : External support has a positive effect on the development of PMS for operational purposes.

$\boldsymbol{H}_{5 b}$ : External support has a positive effect on the development of PMS for incentive purposes.

$\boldsymbol{H}_{5 c}$ : External support has a positive effect on the development of PMS for exploration purposes.

Based on the variables relationship in this study, the research model is formulated as shown in Figure 1. 


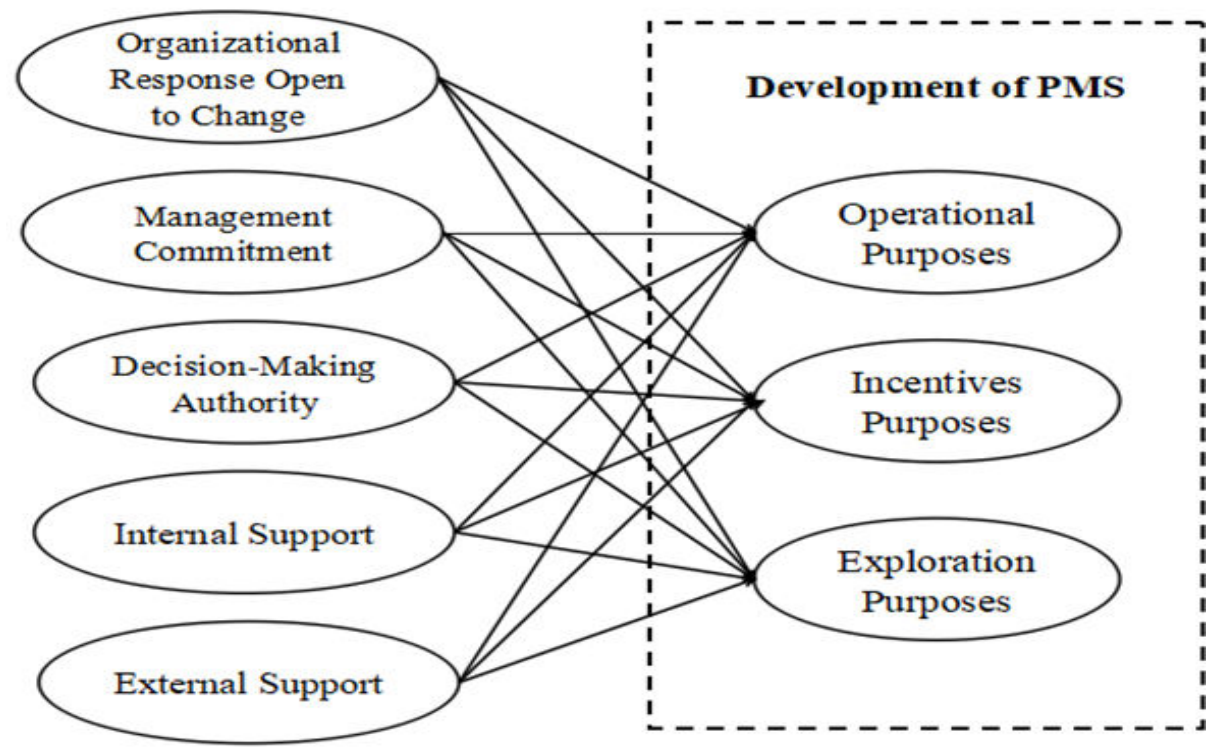

Figure 1 Research Model

\section{Research Method}

This research employed mixed methods with sequential explanatory strategies. The use of mixed methods between quantitative and qualitative in one study is believed to be able to neutralize and even eliminate the biases that arise in each method (Creswell, 2014: 22). Thus this approach is considered more suitable to be used to describe in more detail each phenomenon in research than using only one quantitative or qualitative approach (Creswell \& Clarke, 2011). A sequential explanatory strategy is carried out by analyzing quantitative data and proceeding to explore the results of outliers from quantitative data analysis with further interviews (Cresswell, 2014; 315). The procedures performed in a sequential explanatory strategy include; collection and analysis of quantitative data, collection, and analysis of qualitative data, and interpret the results of the overall analysis (Cresswell, 2014; 316)

This research was conducted at the province of DIY Government, Bantul Regency, Kulon Progo, Sleman, Gunung Kidul, and Yogyakarta City. The object of this research was the regional government agency, namely the Regional Work Unit, including service, agency, and office. The method of sample selection was performed utilizing a sampling purpose with the criteria of minimum echelon IV officials (four) in each Regional Work Unit.

This study induced from the research of Julnes and Holzer (2001), Cavaluzzo and Ittner (2004), and Sihaloho and Halim (2005), as presented in Table 1. Quantitative data collection was carried out by a survey using a questionnaire. Qualitative data collection was done by semi-structured interviews with respondents (quantitative) who were categorized as outliers. Quantitative data analysis utilized SEM-PLS with the consideration that PLS is an analysis of variance-based structural equations that can be 
The Effects of Organizational and Political Factors ...

used simultaneously to test measurement models and structural models (Hartono \& Abdillah, 2014: 14). In addition, PLS requires minimal demands on the measurement scale, sample size, variable distribution, and residual distribution (Chin et al. 2003; Hartono \& Abdillah 2009; Solihin \& Ratmono, 2013; Sofyani \& Akbar, 2013).

Table 1 Operational Definition and Variable Measurement

\begin{tabular}{|c|c|c|c|}
\hline Symbol & Variable Name & Variable definition & $\begin{array}{c}\text { Measurement } \\
\text { Instruments }\end{array}$ \\
\hline ROT & $\begin{array}{l}\text { Organizational } \\
\text { Response Open to } \\
\text { Change }\end{array}$ & $\begin{array}{l}\text { Attitudes and desires of management and } \\
\text { non-management for organizational } \\
\text { implementation and change, and their } \\
\text { understanding of the development of PMS. }\end{array}$ & $\begin{array}{l}\text { Julnes \& } \\
\text { Holzer (2001) }\end{array}$ \\
\hline KOM & $\begin{array}{l}\text { Management } \\
\text { Commitment }\end{array}$ & $\begin{array}{l}\text { Management commitment to support } \\
\text { providing resources in the development of } \\
\text { organizational PMS. }\end{array}$ & $\begin{array}{l}\text { Cavalluzo \& } \\
\text { Ittner (2004) }\end{array}$ \\
\hline OPK & $\begin{array}{l}\text { Decision-Making } \\
\text { Authority }\end{array}$ & $\begin{array}{l}\text { Decision-making authority owned by } \\
\text { managers/respondents in achieving the } \\
\text { organization's strategic goals. }\end{array}$ & $\begin{array}{l}\text { Cavalluzo \& } \\
\text { Ittner (2004) }\end{array}$ \\
\hline DIN & Internal Support & $\begin{array}{l}\text { Internal support is an internal political proxy, } \\
\text { which is a political factor that measures the } \\
\text { extent of leadership and employee support } \\
\text { for performance measures. }\end{array}$ & $\begin{array}{l}\text { Sihaloho \& } \\
\text { Halim (2005) }\end{array}$ \\
\hline DEK & External Support & $\begin{array}{l}\text { External support is an external political proxy } \\
\text { that is legislative and public (public) support } \\
\text { for performance measures. }\end{array}$ & $\begin{array}{l}\text { Sihaloho \& } \\
\text { Halim (2005) }\end{array}$ \\
\hline PTO & $\begin{array}{l}\text { PMS for } \\
\text { operational } \\
\text { purposes }\end{array}$ & $\begin{array}{l}\text { A system that can be applied for operational } \\
\text { purposes. }\end{array}$ & $\begin{array}{l}\text { Speklé \& } \\
\text { Verbeeten } \\
\text { (2014) }\end{array}$ \\
\hline PTI & $\begin{array}{l}\text { PMS for incentive } \\
\text { purposes }\end{array}$ & $\begin{array}{l}\text { A system that can be applied for incentive } \\
\text { purposes. }\end{array}$ & $\begin{array}{l}\text { Speklé \& } \\
\text { Verbeeten } \\
\text { (2014) }\end{array}$ \\
\hline PTE & $\begin{array}{l}\text { PMS for } \\
\text { exploration } \\
\text { purposes. }\end{array}$ & $\begin{array}{l}\text { A system that can be applied for exploration } \\
\text { purposes. }\end{array}$ & $\begin{array}{l}\text { Speklé \& } \\
\text { Verbeeten } \\
\text { (2014) }\end{array}$ \\
\hline
\end{tabular}

Qualitative data analysis employing thematic analysis was one of the techniques of qualitative data analysis to identify, analyze, and report patterns (themes) of data collected by researchers. Thematic analysis is a flexible approach so that it can be used in a variety of epistemological and research questions (Braun \& Clarke, 2006). This technique is believed to be very effective in qualitative research that aims to explore in detail the qualitative data they have to find the relationship of patterns in a phenomenon and explain the extent to which a phenomenon occurs through the lens of researchers (Fereday \& Muir-Cochrane, 2006; in Heriyanto, 2018). The steps of data analysis include: understanding the data, compiling the code, and looking for themes in accordance with the objectives of the study (Heriyanto, 2018). Although the thematic analysis does not require a specific theoretical framework and approach to be used, the use of specific theoretical perspectives as a basis for data analysis is essential to clarify the position of the theory (Braun \& Clarke 2006). This study used the perspective of institutional theory to explain research data. 


\section{Result and Discussion}

Details of the respondents' profile, the response rate, and usable rate can be seen in Table 2 and Table 3.

Table 2 Profile of Respondents

\begin{tabular}{|c|c|c|c|}
\hline \multicolumn{2}{|l|}{ Information } & Total $(\mathrm{N}=136)$ & Percentage / \% \\
\hline \multirow[t]{2}{*}{ Gender } & Male & 96 & 70.588 \\
\hline & Female & 40 & 29.412 \\
\hline \multirow{6}{*}{$\begin{array}{l}\text { Level of } \\
\text { Education }\end{array}$} & Senior High School & 2 & 1.471 \\
\hline & Diploma & 6 & 4.412 \\
\hline & S1 & 68 & 50.000 \\
\hline & S2 & 56 & 41.176 \\
\hline & S3 & 0 & 0.000 \\
\hline & No comment & 4 & 2.941 \\
\hline \multirow[t]{3}{*}{ Position Level } & Echelon IV & 79 & 58.088 \\
\hline & Echelon III & 55 & 40.441 \\
\hline & Echelon II & 2 & 1.471 \\
\hline \multirow{5}{*}{$\begin{array}{l}\text { Length of } \\
\text { Work }\end{array}$} & 2 - 5 year & 1 & 0.735 \\
\hline & 6 - 10 year & 5 & 3.676 \\
\hline & 11 - 15 year & 14 & 10.294 \\
\hline & $>15$ year & 109 & 80.147 \\
\hline & No comment & 7 & 5.147 \\
\hline
\end{tabular}

Non-Response Bias

Non-response Bias test was done using the Mann-Whitney test based on two different questionnaire collection stages (stage 1: 98 questionnaires, and stages 2: 38 questionnaires). Testing for non-response bias between different groups of regions (local government) was carried out employing the Kruskal-Wallis Test (Supangat, 2007). The results of the Mann-Whitneytestand the Kruskal-Wallis Test showed the value of Asymp. Sig (2-tailed) for each variable $>0.05$. It showed that there was no difference in response between different groups (refer to Table 3 ).

Table 3 Details of Response Rate and Usable Response Rate

\begin{tabular}{lccccc}
\hline Local Government & Send & Back & $\%$ & Processed & $\%$ \\
\hline Yogyakarta City & 23 & 21 & 13.816 & 20 & 13.158 \\
Bantul Regency & 30 & 29 & 19.079 & 28 & 18.421 \\
Kulon Progo Regency & 24 & 22 & 14.474 & 22 & 14.474 \\
Gunung Kidul Regency & 25 & 23 & 15.132 & 20 & 13.158 \\
Sleman Regency & 25 & 24 & 15.789 & 23 & 15.132 \\
DIY Provincial Government & 25 & 24 & 15.789 & 23 & 15.132 \\
Total & 152 & 143 & 94.079 & 136 & 89.474 \\
\hline
\end{tabular}

Figure 2 shows the measurement model that has been made using SmartPLS 2.0 M3. 


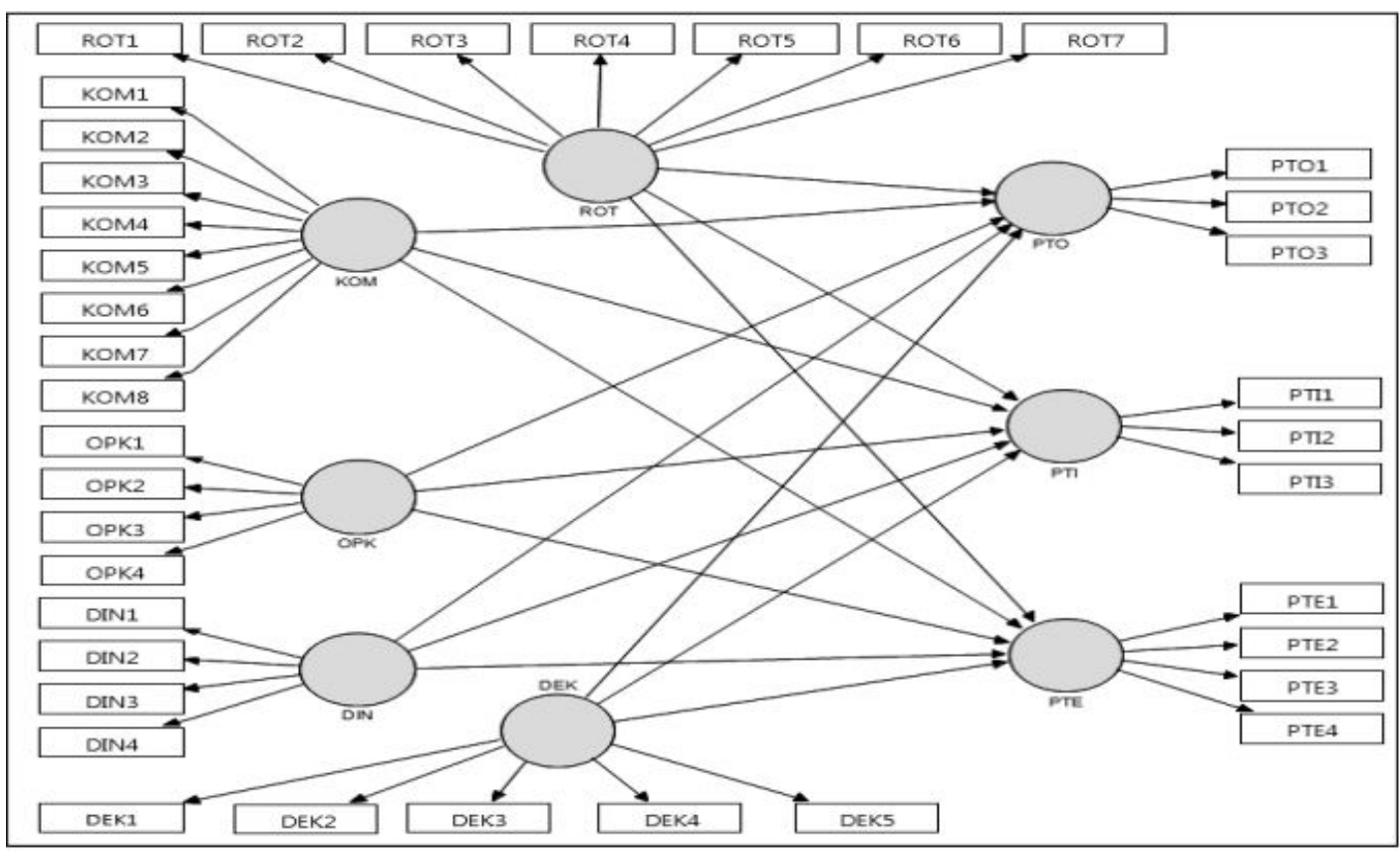

Figure 2 Measurement Model

Testing the measurement model included construct validity (convergent validity and discriminant validity) testing and instrument reliability testing. After the PLS algorithm iteration processed, the data obtained in Table 4 were collected. Convergent validity tests were carried out by looking at the value of AVE and communality. From Table 4, it can be seen that all constructs in this study met the convergent validity requirements because the values of AVE and communality for all constructs were $>0.5$. It indicated that the probability of the indicators that entered into each of the related constructs was higher than those that entered other constructs.

Determinant validity test was done by looking at the cross-loading value of each indicator in the required construct that shouldbe $>0.7$, or between $0.5-0.7$, as long as the AVE and communality values show a value of $>0.5$ (Hartono \& Abdillah, 2014; 61). The results of the PLS algorithm iteration process also indicated that the value of crossloading of each indicator in each construct was higher than the indicator in other constructs, which was >0.6. The data in Table 3 also shows the AVE value and the communality of all variables $>0.5$. Thus, it can be concluded that each indicator in each construct in the measurement model of this study has met the discriminant validity requirements.

A reliability test was used to measure the internal consistency of a measuring instrument. The reliability test in PLS can use two methods, namely Cronbach's alpha and composite reliability. A construct is said to be reliable if the value of Cronbach's alpha $>0.6$, and value composite reliability $>0.7$ (Hartono \& Abdillah, 2014; 81). Table 3 shows that value Cronbach's alpha constructs $>0.6$, and composite reliability values construct $>0.7$, respectively. Based on these data, it can be concluded that the entire 
construct in this study fulfilled the reliability and reliability requirements, or was feasible to use for testing hypotheses.

Table 4 Overview of Results of Iteration of PLS Algorithm

\begin{tabular}{lcccccc} 
Construct & AVE & $\begin{array}{c}\text { Composite } \\
\text { Reliability }\end{array}$ & $\begin{array}{c}\mathrm{R} \text { Square } \\
\left(\mathbf{R}^{2}\right)\end{array}$ & $\begin{array}{c}\text { Cronbach's } \\
\text { Alpha }\end{array}$ & Communality & Redundancy \\
\hline DEK & 0.676 & 0.912 & & 0.880 & 0.676 & \\
DIN & 0.610 & 0.861 & & 0.786 & 0.610 & \\
KOM & 0.694 & 0.947 & & 0.937 & 0.694 & \\
OPK & 0.685 & 0.896 & & 0.860 & 0.685 & \\
PTE & 0.700 & 0.903 & 0.308 & 0.858 & 0.700 & 0.057 \\
PTI & 0.700 & 0.875 & 0.426 & 0.786 & 0.700 & 0.167 \\
PTO & 0.629 & 0.835 & 0.361 & 0.702 & 0.629 & 0.134 \\
ROT & 0.637 & 0.925 & & 0.906 & 0.637 & \\
\hline
\end{tabular}

Note: DEK: External-Support; DIN: Internal-Support; KOM: Management commitment; OPK: Decision-Making Authority; PTE: PMS for exploration purposes; PTI: PMS for incentive purposes; PTO: PMS for operational purposes; ROT: Organizational Response Open to Change.

Evaluation of the structural model (inner model) was done by looking at the value of $R$ square (R2) in the table of results of the iteration of the PLS algorithm. The higher the value of $R$ square ( $R 2$ ), the better the proposed research model (Hartono \& Abdillah, $2014 ; 62$ ). Based on the data in Table 4 , it is known that the value of $R$ square (R2) of each endogenous construct in this research model was 0.308 (PTE), 0.426 (PTI), 0.361 (PTO). Based on these data, it can be concluded that the construct variance in the development of PMS for operational, incentive, and exploration purposes were only able to be explained by exogenous constructs (ROT, KOM, OPK, DIN, and DEK) of $30.8 \%$ (PTE), $42.6 \%$ (PTI) ), and 36.1\% (PTO), while the remainder was explained by other variables outside of this study.

Testing the hypothesis in this study was carried out by looking at the output data of the process bootstrapping in PLS. The hypothesis is supported if the direction of the data coefficient of bootstrapping results is the same as the prediction properties in the hypothesis submitted and t-statistic $>1.64$.

Table 5 shows the summary of hypothesis testing results. Based on the output data from the bootstrapping process, it can be concluded that hypotheses 1a, 1b, 1c, 3c, 4a, 4b, 4c, $5 b, 5 c$ were supported, and hypotheses $2 a, 2 b, 2 c, 3 a, 3 b, 5 c$ were not supported, as presented in the summary of the test results hypothesis.

The selection of respondents' data in the outlier category is one way to choose samples for the qualitative stage (Creswell \& Plano, 2011). It was done by graphing scatterplots using MS Excel. Based on the scatterplots graph of the distribution of respondents' data, it can be obtained from several respondents who were in the outlier category. However, after being confirmed, only six respondents were willing to be interviewed (Table 6). 
Parwoto \& Halim

The Effects of Organizational and Political Factors ...

Table 5 Summary of Hypothesis Testing Results

\begin{tabular}{|c|c|c|c|c|}
\hline Correlation & Hypothesis & $\begin{array}{c}\text { Coefficient } \\
\text { (Original Sample) }\end{array}$ & T Statistics & Result \\
\hline ROT $\rightarrow$ PTO & $\mathrm{H} 1 \mathrm{a}(+)$ & 0.270 & 2.953 & Supported \\
\hline ROT $\rightarrow$ PTI & $\mathrm{H} 1 \mathrm{~b}(+)$ & 0.382 & 3.517 & Supported \\
\hline $\mathrm{ROT} \rightarrow \mathrm{PTE}$ & $\mathrm{H} 1 \mathrm{c}(+)$ & 0.405 & 5.014 & Supported \\
\hline KOM $\rightarrow$ PTO & $\mathrm{H} 2 \mathrm{a}(+)$ & -0.263 & 2.261 & Not supported \\
\hline KOM $\rightarrow$ PTI & $\mathrm{H} 2 \mathrm{~b}(+)$ & -0.202 & 1.785 & Not supported \\
\hline $\mathrm{KOM} \rightarrow \mathrm{PTE}$ & $\mathrm{H} 2 \mathrm{c}(+)$ & -0.174 & 1.631 & Not supported \\
\hline OPK $\rightarrow$ PTO & H3a (+) & 0.165 & 1.387 & Not supported \\
\hline $\mathrm{OPK} \rightarrow \mathrm{PTI}$ & $\mathrm{H} 3 \mathrm{~b}(+)$ & 0.091 & 1.070 & Not supported \\
\hline OPK $\rightarrow$ PTE & $\mathrm{H} 3 \mathrm{c}(+)$ & 0.263 & 1.702 & Supported \\
\hline DIN $\rightarrow$ PTO & $\mathrm{H} 4 \mathrm{a}(+)$ & 0.353 & 2.863 & Supported \\
\hline DIN $\rightarrow$ PTI & $\mathrm{H} 4 \mathrm{~b}(+)$ & 0.311 & 2.733 & Supported \\
\hline DIN $\rightarrow$ PTE & $\mathrm{H} 4 \mathrm{c}(+)$ & 0.179 & 1.743 & Supported \\
\hline DEK $\rightarrow$ PTO & H5a (+) & 0.296 & 3.213 & Supported \\
\hline $\mathrm{DEK} \rightarrow \mathrm{PTI}$ & H5b (+) & 0.318 & 3.926 & Supported \\
\hline DEK $\rightarrow$ PTE & $\mathrm{H} 5 \mathrm{c}(+)$ & 0.148 & 1.423 & Not supported \\
\hline
\end{tabular}

Note: DEK: External-Support; DIN: Internal-Support; KOM: Management commitment; OPK: Decision-Making Authority; PTE: PMS for exploration purposes; PTI: PMS for incentive purposes; PTO: PMS for operational purposes; ROT: Organizational Response Open to Change.

Table 6 Respondent Profile Data Interview

\begin{tabular}{|c|c|c|c|c|}
\hline Respondent & Agency & $\begin{array}{l}\text { Local } \\
\text { Government }\end{array}$ & Position & Gender \\
\hline R.4 & $\begin{array}{l}\text { Badan Perencanaan } \\
\text { Pembangunan Daerah } \\
\text { (Development Planning } \\
\text { Agency at Sub-National Level) }\end{array}$ & $\begin{array}{l}\text { Yogyakarta } \\
\text { City }\end{array}$ & $\begin{array}{l}\text { Kabid Litbang (Head of } \\
\text { Research and } \\
\text { Development) }\end{array}$ & $\mathrm{L}$ \\
\hline R.42 & $\begin{array}{l}\text { Dinas Sumber Daya Air } \\
\text { (Water Resources Agency) }\end{array}$ & $\begin{array}{l}\text { Bantul } \\
\text { Regency }\end{array}$ & $\begin{array}{l}\text { Kasubbag Program (Head } \\
\text { of sub-section of the } \\
\text { program) }\end{array}$ & L \\
\hline R. 68 & $\begin{array}{l}\text { Dinas Kelautan Perikanan dan } \\
\text { Peternakan (Marine, Fisheries } \\
\text { and Livestock Agency) }\end{array}$ & $\begin{array}{l}\text { Kulon Progo } \\
\text { Regency }\end{array}$ & $\begin{array}{l}\text { Kasubbag Program \& } \\
\text { Informasi (Head of sub- } \\
\text { section of the program and } \\
\text { information) }\end{array}$ & $\mathrm{P}$ \\
\hline R.75 & $\begin{array}{l}\text { Badan Perencanaan } \\
\text { Pembangunan Daerah } \\
\text { (Development Planning } \\
\text { Agency at Sub-National Level) }\end{array}$ & $\begin{array}{l}\text { Gunung Kidul } \\
\text { Regency }\end{array}$ & $\begin{array}{l}\text { Kabid Pem.Sosial \& Budaya } \\
\text { (Head of social and cultural } \\
\text { development) }\end{array}$ & $\mathrm{L}$ \\
\hline R.100 & $\begin{array}{l}\text { Badan Penanggulangan } \\
\text { Bencana Daerah (Regional } \\
\text { Disaster Management } \\
\text { Agency) }\end{array}$ & $\begin{array}{l}\text { Sleman } \\
\text { Regency }\end{array}$ & $\begin{array}{l}\text { Kasubbag Program \& } \\
\text { Informasi ((Head of sub- } \\
\text { section of the program and } \\
\text { information)) }\end{array}$ & $\mathrm{L}$ \\
\hline R.124 & $\begin{array}{l}\text { Dinas Pertanian (Department } \\
\text { of Agriculture) }\end{array}$ & $\begin{array}{l}\text { DIY Provincial } \\
\text { Government }\end{array}$ & $\begin{array}{l}\text { Kabid Perencanaan (Head } \\
\text { of planning) }\end{array}$ & $\mathrm{L}$ \\
\hline
\end{tabular}

The interviews with six respondents were conducted in the institutions of each respondent with a period of between 25-60 minutes. Interviews were carried out from September 26-30, 2016, adjusting the time provided by the respondents. The interview technique used was by conducting interviews directly (face to face interview), semi- 
structured and open, and recording it with an audio recorder; then, transcribed and recorded the ideas that emerged from the results of the transcript (Creswell, 2014; 272).

The theme used to analyze the results of interviews was the influence of an open organizational response to change, management commitment, decision-making authority, internal support, and external support to develop PMS. The phenomenon of institutional isomorphism in the development of PMS, namely coercive isomorphism, is identified by referring to the phrase "the organization is under pressure to become or carry out certain actions". Mimetic isomorphism refers to the phrase "organizations mimic or copy each other" or "just fulfill formal requirements (formalities)". Next, normative isomorphism refers to the phrase "professionalism in carrying out tasks" (Dacin, 1997 in Akbar et al., 2012)

Tests of reliability and validity were carried out by procedure; 1 ) examining the data and results of quantitative data processing to build justification of the themes and questions, 2) reconfirming respondents 'answers at the end of each interview to ensure the accuracy of respondents' answers, and 3) re-examining the transcript results to ensure that there are no errors in the transcription process interview (Creswell, 2014; 285).

Based on the analysis of the results of the interviews on the content of the theme, an illustration was obtained that; 1 ) the core answers from the respondents supported the overall results of hypothesis testing in the quantitative data processing. 2) Institutional phenomena of isomorphism (coercive, mimetic, and normative) in the PMS development process was also indicated in the answers from interview respondents.

\section{Discussion}

The results of data analysis through two approaches (quantitative and qualitative) used in this study have illustrated the influence of organizational factors and political factors on the purpose of developing PMS and the existence of institutional isomorphism phenomena (coercive, mimetic, and normative) in the process of developing PMS in regional government agencies.

Organizational responses that were open to empirical changes had a positive effect on all PMS development goals, illustrating that the attitude of local government agency apparatus who were open to accepting and adapting to changes in work culture determined the achievement of PMS development goals. This finding is consistent with Julnes and Holzer (2001), who stated that the attitude of organizational members in responding to change had a positive effect on the implementation of PMS. The results of this study are also in line with Sofyani and Akbar (2013), Nurkhamid (2008), and Yowi (2011), as well as complementing Syachbrani's (2013) findings. Local government agencies consider that the development of PMS is innovation and a new system that is very useful to improve the quality of performance of local government institutions. It was supported by the results of the interview as follows:

"... my friends' attitude towards developing performance measures, especially echelon 3 and below ... is quite good, they are open and very supportive ...". (R.4) 
"... Even though there are changes and the mechanism is more complicated ... my friends here are enthusiastic." (R.42)

"... Yes, we have been running PMS ... so far, the response from management friends is quite good, there is no problem, ... Yes, very influential. If they do not respond well ... how is this possible? Implementation \& PMS development can be realized ... "(R.68)

"... Apparatus of the local government agency, understand that this is an effort to regulate the Regional Work Units better... so that the performance of the institution, which is more measurable than before is unclear because it only uses qualitative indicators ..." (R 0.75)

"... if my friends at the regional government institutions lack response and support, then don't expect PMS development to be carried out ..." (R.124)

Empirical management commitment did not have a positive effect but instead had a negative effect on all PMS development goals. Although the results of this study differ from Nurkhamid (2008), Yowi (2011), Sofyani and Akbar (2013), and Primarisanti (2013), these findings are in line with Syachbrani (2013). This finding showed that management commitment that has been shown by the leadership (regional) was not able to encourage the development of PMS for operational needs, incentives, and exploration. In line with the opinion of GAO (2005), the implementation of performance-oriented performance measurement would not succeed without a strong commitment from politicians and senior officials in the US federal government. Local government agency officials assessed the lack of commitment shown by local government leaders, could be felt from the lack of budget allocation and time of achievement, lack of use of performance information to develop and improve performance measurement indicators, and the unavailability of reward and punishment systems based on actual performance. Lack of management commitment caused the PMS development process not to run as expected, only limited to meeting administrative compliance (only formalities). It was supported by the results of interviews with respondents, as follows:

"... He ... he ... this is the problem ... leadership commitment is still lacking ... although leadership commitment is very important and decisive, here the opposite is happening ... Finally, yes the strategic plan document, the development of indicators performance, in my opinion, is only a formality, which is important to meet administrative requirements ..., so it is not made to improve the actual performance ... "(R .4)

"This is our weak point, ... that changes (PMS development) compiled by friends in local government institutions cannot be realized because the leadership factor is not brave enough to take risks, let alone rewards and punishments based on actual performance, not yet implemented... "(R.75)

"....I consider the commitment of the leadership in efforts to improve performance is still lacking, and ... tend which to be important is there, only formal standards ..." (R.42, and R.100) 
The results of quantitative data analysis also proved empirically that decision-making authority only had a positive effect on the development of PMS for exploration purposes. Although the findings of this study, in particular the influence of decisionmaking authority on the development of PMS for exploration purposes, differ from Sofyani (2013), it is in line with the findings of Nurhamid (2008) and Primarisanti (2013). The results of this study indicated that the authority possessed by local government agencies has been able to encourage the development of PMS for exploration purposes, despite failing to meet operational objectives and incentives. This condition was caused by the application of staffing regulations, which regulated decision making authority for local government institutions. The implementation of staffing regulations limited the authority held by the local government agency apparatus. It, in turn, impeded the PMS development process undertaken (Cavaluzzo and Ittner, 2004). Apparatus of local government institutions, as regulated in staffing regulations, are given broad scope and authority in terms of program planning and development. However, in the case of the decision to determine the program to be implemented and the budget allocation is the authority of regional leaders. It was revealed in the interview with respondents as follows:

"... For the authority of the decision-maker, it is regulated in the Regional Regulation. The final decision-making authority rests with the leader of regional, including the final decision regarding the development of PMS ..." (R.4, and R.124)

"... in our rule, our authority is limited to the preparation or design of proposals, proposing and implementing decisions in a professional manner ... the decision-making authority regarding the program to be implemented and the budget allocation rests with the leader of regional ..." (R.42, R. 68 and R.75)

"So far, we have always been involved and given broad enough authority to compile and improve performance indicators and performance targets... but the decision remains with leadership, including the policy direction determined by regional leadership through the Regional Planning and Development Agency (RPDA) as a director ... "(R .100)

Internal support has been proven empirically to have a positive effect on the development of PMS for operational, incentive, and exploration purposes. It indicated that the support and involvement of internal management in the development and evaluation of performance measures and minimizing conflict were strong enough. Due to strong involvement and support from the personnel of the regional government institutions as a whole, the PMS development process to improve performance could be realized. Consistent with Julnes and Holzer's (2001) research, internal stakeholder participation had a positive effect on the process of developing performance measures. The results of this study are also consistent with Diptyana and Basuki (2010), who stated that internal support had a positive effect on the process of developing performance measurement. These findings were supported by the results of interviews with respondents, as follows: 
The Effects of Organizational and Political Factors ...

\begin{abstract}
"Yes ... we at internal institutions are very supportive and are always involved in the implementation and development of performance measurements. ... we are the implementers. ... differences of opinion in discussions, that's normal ..." (R4, and Q.42). "... Yes, we are always involved in the development of PMS, from preparation to implementation, all are involved in stages. Debates are common, but after it has been decided, friends here continue to support and implement it as best as possible to achieve the targets set ... they are professional and compact. "(R.68)

"... even though the planned development and the increase in size and performance targets that have been prepared, cannot be realized because we must adjust the leadership policy and the availability of funds. We all internally in regional institutions, consistently support and implement as well as possible..." (R.75)

"...When discussing program proposals between divisions/fields ... debates are common. However, after being decided by the leadership, my friends still support to make the best decision in accordance with their respective duties and functions...."

(R.100, and R.124)
\end{abstract}

Empirical external support has only been proven to have a positive effect on the development of PMS for operational purposes and incentives. This finding showed that external support that has been provided by the community and the legislature has not been able to encourage the development of PMS for exploration purposes. Apparatus from local government agencies saw the support provided by the legislature was not serious in implementing the development of performance measures to improve the quality of performance. Legislative support was limited to the development of performance indicators that were initially qualitative to quantitative and performance targets for individuals and collectives. The legislature was considered not to have used performance information optimally so that legislative support was not balanced with adequate budget allocations. Thus, the development carried out by PMS was only limited to meeting formal standards. Also, the incentive scheme was not based on actual performance. This finding is in line with Wang (2000), Julnes and Holzer (2001), Diptyana and Basuki (2010), who showed that external support significantly influenced the development of performance measures. This finding was supported by the respondents' answers in the interview, as follows:

"...The legislature has been very supportive and encouraging the development of performance measurement. However, yes ... because the budget allocation is limited and the leadership does not dare to take risks ... so it's the same ... finally, the strategic plan document, only standard performance indicators ... the important thing has been met formal standards. As is the case with incentives ... from the start, that's all ... ". (R.4)

"..I feel legislative support as if it's just a formality. Because support for program planning is not balanced with adequate budget allocations. I feel the budget allocation is not based on the previous year's performance ... ". (R.42 and R.100)

"The community and the legislature are very supportive, even Regional Regulations have been made. It's just ... everything is constrained by limited budget allocations ..." (R.68, and R.75) 
The Effects of Organizational and Political Factors ...

"... Public and legislative support is quite high for the development of PMS ... but I think the local government and legislature have not used performance information optimally, so the budget is allocated regardless of program performance and the quality of program proposals". (R.124)

In addition, the results of the qualitative analysis illustrated the phenomenon of institutional isomorphism that occurred in the process of developing PMS in regional government agencies. Coercive isomorphism was indicated by respondents' answers, stating that the main motivation of local government officials to develop PMS was due to regulatory demands from the central government and regional governments.

"... The implementation and development of PMS ... it is the mandate of the central government ... we must implement it, mas ..." (R. 75)

"... yes ... the main motivation is to fulfill the central government's mandate and the demands of the Local Regulation, ..." (R.100)

"... yes, indeed, we are required to implement it in accordance with the Local Regulation, ... the implementation and development of the PMS is the mandate of the central government. As regional institutions, we must obey the central rules ... "(R.124, and R.42)

Mimetic isomorphism was indicated by the answers of several respondents who stated that until now, local government agencies in compiling performance indicators still tended to imitate the targets or achievements of previous period performance. Therefore, in the end, the agreed indicators tended only to fulfill formal requirements (formalities) and have not been aimed at fulfilling community expectations or performance accountability. This condition was partly due to the lack of commitment of the leadership and the limited authority possessed by the apparatus of local government agencies to improve the quality of performance.

"..so the development of PMS is only at the level of formality. Just like that from year to year.." (R.75)

"... if copying from another institution, it is not, because each institution has a different function, bro ... However, if the programs and indicators are often the same as the previous year, maybe yes, for example, only the numbers are different ... because often leaders don't dare to take risks ... "(R.68)

"... finally, the strategic plan document, the performance indicators produced are only standards ... what matters is that there are documents and only meet formal standards. Likewise, with incentives ... from the start, it remains that way without improvement ..." (R .4)

"... I consider leadership commitment in efforts to improve performance still lacking, and what is important is that performance measurement documents exist, so they only meet formal standards ..." 
Normative isomorphism was indicated by the answers of several respondents who stated that knowledge was obtained only from socialization from relevant agencies, such as the Ministry of Home Affairs (Mendagri), KemenPAN-RB, and internal agencies such as BAPPEDA. However, this knowledge has influenced the development of the cognitive basis of the apparatus of regional government agencies, which ultimately influenced behavior, a spirit of togetherness, and independence to proceed to develop PMS for better organizational change, according to community expectations and regulatory demands. Although the impact of these changes has not yet been seen in improving the quality of performance indicators because of constraints on the commitment of less supportive leaders and the limited authority possessed, it has indicated that there was professionalism in carrying out the tasks indicated by regional government officials, especially echelon III and IV.

"... yes, there was socialization and assistance from the Regional Planning and Development Agency (RPDA) ... we were assisted in compiling and developing performance measurements ... from there we learned ..." (R.100)

"... we are supported by our internal team who have received training from the central government and then we involve all institutions to jointly learn to compile and developing performance measures ... "(R. 75)

"... related to the development of PMS, there are socialization and assistance from Regional Planning and Development Agency (RPDA), which is intensive in providing assistance and consultation to us so that we can do it ..." (R.42)

"... in the development of performance measurement, we were mentored and accompanied by Regional Planning and Development Agency (RPDA) ..." (R.68)

\section{Conclusion}

Based on the results of quantitative and qualitative data analysis, it was found that to support the success of the PMS development process in local government institutions needed an open attitude from the local government apparatus in accepting changes, strong commitment from the leaders, broad enough authority for the local government apparatus, and strong political support from internal and external. In addition, the results of qualitative data analysis also show that the phenomenon of institutional isomorphism which includes coercive, mimetic, and normative is indicated in the PMS development process in local government institutions. Coercive isomorphism is indicated from the main motivation of the PMS development process carried out by local government apparatus, namely to meet regulatory pressure from the central government. This is reasonable considering that the regional government as part or subordinate of the central government must submit and adjust to the regulations set by the central government as the supporting institution. However, due to a lack of courage to take risks that show a lack of commitment from the leaders and a lack of external support from the legislature, as well as limited authority of local government apparatus, the purpose of the PMS development process is only to fulfill formal requirements. This practice is a form of mimetic isomorphism. Furthermore, the existence of socialization 
and training from related institutions such as the Ministry of Home Affairs, KemenPANRB through Bappeda to increase the knowledge of local government apparatus about how the PMS development process should be carried out, is one form of normative isomorphism.

The results of this study provide important notes to local governments, especially in the province of DIY regarding the factors that need to be considered in the PMS development process. So that the PMS development policy is successful and can improve local government performance. The results of this study complement previous research on the factors that influence the development of PMS and add evidence that the phenomenon of institutional isomorphism exists in the PMS development process. Research in this field has not been much researched in public sector accounting, particularly in Indonesia.

The minimum number of respondents who are willing to be interviewed and the research sample is only limited in the province of DIY is a limitation in this study that might affect the results. Further research is recommended to continue using the mixed methods by expanding the distribution area of the sample used and adding other variables that are considered influential and able to capture the phenomenon of institutional isomorphism in the PMS development process.

\section{References}

Ahyarudin, M., \& Akbar, R. (2017). Akuntabilitas dan Kinerja Instansi Pemerintah: Semu atau Nyata. Jurnal Akuntansi \& Auditing, 21 (2), 105-117. https://doi.org/10.20885/jaai.vol21.iss2.art3

Akbar, R., Pilcher, R., \& Perrin, B. (2012). Performance Measurement in Indonesia: The Case of Local Government. Pasific Accounting Review, 24 (3), 262-291. https://doi.org/10.1108/01140581211283878

Ashworth, R., Boyne, G., \& DelBridge, R. (2009). Escape from the Iron Cage? Organizational Change and Isomorphic Pressure in the Public Sector. Journal of Public Administration Research and Theory, 19(1), 165-187. https://doi.org/10.1093/jopart/mum038

Berman, E., \& Wang, X. (2000). Performance Measurement in US Counties: Capacity for Reform. Public Administration Reviews, 60 (5), 409-420. https://doi.org/10.1111/0033$\underline{3352.00104}$

Braun, V., \& Clarke, V. (2006). Using Thematic Analysis in Psychology. Journal Qualitative Research in Psychology, 3 (2), 77-101. https://doi.org/10.1191/1478088706qp063oa

Buckho, A. (1994). Barries to Strategic Transformation. Advances in Strategic Management, 10, 81-106. Retrieved from https://www.researchgate.net/publication/286125618 Barriers to strategic transfor mation

Cavalluzo, K. S., \& Ittner, C. (2004). Implementing Performance Measurement Innovations: Evidence From Government. Accounting, Organizations, and Society, 29, 243-267. http://dx.doi.org/10.1016/S0361-3682(03)00013-8 
Cohen, S. D. (2014). Reporting Performance Information in the Public Sector: The Moral Behind the (non) Application of Program Budgeting in Greece. International Review of Administration Sciences, 80 (3), 619-636. https://doi.org/10.1177/0020852313517998

Creswell, J. W. (2014). Research Design: PendekatanKuantitatif, Kualitatifdan Mixed (Versi Terjemahan). Yogyakarta: PustakaPelajar.

Creswell, J. W., \& Plano, C. V. (2011). Designing and Conducting Mixed Methods Research, Second Edition. Sage Publications: Los Angeles

DiMaggio, P. J., \& Powell, W. W. (1983). The Iron Cage Revisited: Institutional Isomorphism and Collective Rationality in Organizational Fields. American Sociological Review. 48, 147-160. https://doi.org/10.2307/2095101

Diptyana, P., \& Basuki, H. (2010). Pengembangan dan Pemanfaatan Informasi Kinerja Untuk Penganggaran di Instansi Pemerintah D.I Yogyakarta Ditinjau Dari Dukungan Internal dan Eksternal Serta Kapabilitas Teknis. Majalah Ekonomi, Tahun XX, No. 2. Retrieved from https://media.neliti.com/media/publications/4095-IDpengembangan-dan-pemanfaatan-informasi-kinerja-untuk-penganggaran-di-instansipe.pdf

Field, A. (2009). Discovering Statistics Using SPSS. London: Sage.

Frumkin, P., \& Galaskiewicz. (2004). Institutional Isomorphism and Public Sector Organizations. Journal of Public Administration Research and Theory. 14 (3), 283-307. www.jstor.org/stable/3525838

GAO. (2005). Performance Measurement and Evaluation Definitions and Relationships, Gaithersburg, GAO-05-739SP: MD: General Accounting Office.

Gron, C.H., \& Salomonsen, H.H. (2017). Political Instability and The Ability of Local Government to Respond to Reputational Threats in Unison. International Review of Administrative Science, 85 (3), 440-456. https://doi.org/10.1177/0020852317714533

Hartono, J., \& Abdillah, W. (2014). Konsep dan Aplikasi PLS (Partial Least Square) Untuk Penelitian Empiris. Yogyakarta: BPFE.

Hinterleitner, M. (2018). Policy Failure, Blame Games and Changes to Policy Practise. Journal of Public Policy, 38 (2), 221-242. https://doi.org/10.1017/S0143814X16000283

Julnes, P. d., \& Holzer, M. (2001). Promoting the Utilization of Performance Measures in Public Organization: an Empirical Studi of Factor Affecting Adoption and Implementation. Public Administration Review 61 (6), 693-708. http://dx.doi.org/10.1111/0033-3352.00140

Mardiasmo. (2009). Akuntansi Sektor Publik, Ed IV, Penerbit ANDI, Yogyakarta.

Masuku, M. M., \& Jili, N. N. (2019). Public Service Delivery in South Africa: The Political Influence at Local Government Level. Journal Public Affair, 19 (4). https://doi.org/10.1002/pa.1935

Meyer, J., \& Rowan, B. (1977). Institutionalized Organizations: Formal Structure as Myth and Ceremony. American Journal of Sociology, 83, 340-63. https://www.jstor.org/stable/2778293

Morrow, J., \& Hitt, M. A. (2000). Rational and Political Models of Strategic Decision Making: Understanding the Role of Firm Performance and Stakeholder Political Pressure. Handbook of Strategic Management, 2nd Edition, Marcel Dekker, Inc: 165-179.

Nurkhamid, M. (2008). Implementasi Inovasi Sistem Pengukuran Kinerja Instansi Pemerintah. Jurnal Akuntansi Pemerintah, 3, (1), 45 -76. Retrieved from https: / $/$ www.google.com/url? sa $=\mathrm{t} \& \mathrm{rct}=j \& \mathrm{qq}=\& \mathrm{esrc}=\mathrm{s} \&$ source $=\mathrm{web} \& \mathrm{~cd}=1 \& \mathrm{cad}=\mathrm{rja}$ \&uact $=8 \& v e d=2 a h U K E w j B w s 29 \quad$ e7oAhUbU30KHWbsBLQQFjAAegQIAhAB\&ur l=https $\% 3 \mathrm{~A} \% 2 \mathrm{~F} \% 2 \mathrm{Fdocplayer}$.info $\% 2 \mathrm{~F} 49473376$-Jurnal-akuntansi-pemerintah-vol3-no-1-oktober-2008-hal.html\&usg=AOvVaw3GL4HsKy YQNC4adR7uIaa 
Primarisanti, H., \& Akbar, R. (2015). Factors Influencing the Success of Performance Measurement: Evidence from Local Government. Journal of Indonesian Economy and Business, 30 (1): 56-71. https://doi.org/10.22146/jieb.7334

Rainey, H. G. (1999). Using Comparisons of Public and Private Organizations to Assess Innovative Attitudes Among Members of Organizations. Public Productivity and Management Review, 23 (2), 130-149. https://doi.org/10.2307/3380775

Robbins, S., \& Judge, A. (2011). Organizational Behavior. New Jersey: Pearson.

Sihaloho, F. L., \& Halim, A. (2005). Pengaruh Faktor-Faktor Rasional, Politik, dan Kultur Organisasi Terhadap Pemanfaatan Informasi Kinerja Instansi Pemerintah Daerah. Simposium Nasional Akuntansi VIII Solo. Retrieved from https://smartaccounting.files.wordpress.com/2011/03/kasppa-02.pdf

Sofyani, H., \& Akbar, R. (2013). Hubungan Faktor Internal Institusi dan Implementasi Sistem Akuntabilitas Kinerja Instansi Pemerintah (SAKIP) di Pemerintah Daerah. Jurnal Akuntansi dan Keuangan Indonesia, 10, (2), 184-205. https://doi.org/10.21002/jaki.2013.10

Sofyani, H., Akbar, R., \& Ferrer, R. C. (2018). 20 Years of Performance Measurement System (PMS) Implementation in Indonesian Local Governments: Why is Their Performance Still Poor?. Asian Journal Business and Accounting, 11, (1), 151- 184. https://doi.org/10.22452/ajba.vol11nol.6

Speklé, R. F., \& Verbeeten, F. H. (2014). The Use of Performance Measurement System in The Public Sector: Effects on Performance. Management Accounting Research, 25(2), 131146. http://dx.doi.org/10.1016/i.mar.2013.07.004

Supangat, A. (2007). Statistika dalam Kajian Deskriftif, Inferensi dan Nonparametrik. Edisi Pertama. Jakarta: Kencana Prenada Media Group

Syachbrani, W. (2013). Pengaruh Faktor-Faktor Teknis dan Keorganisasional yang Mempengaruhi Pengembangan Sistem Pengukuran Kinerja Pemerintah Daerah. Jurnal Reviu Akuntansi dan Keuangan. 3, (2), 447-464. https://doi.org/10.22219/jrak.v3i2.2112

The Urban Institute. (2002). How and Why Nonprofits Use Outcome Information. The Urban Institute, Washington DC. Retrieved from https://www.urban.org/sites/default/files/publication

Toshkov, D., Mader, L., \& Rasmussen, A. (2018) Party Government and Policy Responsiveness. Evidence From three Parliamentary Democracies. Journal Of Public Policy, 1-19. https://doi.org/10.1017/S0143814X18000417

Wang, X (2000) Performance Measurement in Budgeting: A study of Country Governments. Public Budgeting \& Finance. Fall 2000, 102-118. Retrieved from https://www.researchgate.net/deref/http $\% 3 \mathrm{~A} \% 2 \mathrm{~F} \% 2 \mathrm{Fdx}$.doi.org $\% 2 \mathrm{~F} 10.1111 \% 2 \mathrm{~F} 02$ 75-1100.00022

Wicki, M., Huber, R.A., \& Berauer, T. (2019). Can Policy Packaging Increase Public Support for Costly Policies? Insights From a Choice Experiment on Policies Against Vehicle Emissions. Journal of Public Policy, 1-27. https://doi.org/10.1017/s0143814x19000205

Wijaya, A. H. C, \& Akbar, R. (2013). The Influence of Information, Organizational Objective and Targets, and External Pressure toward The Adoption of Performance Measurement System in Public Sector. Journal of Indonesian Economy and Business, 28 (1), 62- 83. https://doi.org/10.22146/jieb.6230

Yowi, L. R. K. (2011). The Correlation Among The Factors of Implementation, The System Development, and the Result of Performance Measurement System: A Study Conducted in the Regency of Sumba Timur), Journal of Indonesian Economy and Business 26 (3), 2011, 371-388. https://doi.org/10.22146/jieb.6264 